\title{
Validation List no. 97 Validation of publication of new names and new
combinations previously effectively published
outside the IJSEM
}

The purpose of this announcement is to effect the valid publication of the following new

Correspondence

Jean Euzéby

j.euzeby@envt.fr names and new combinations under the procedure described in the Bacteriological Code (1990 Revision). Authors and other individuals wishing to have new names and/or combinations included in future lists should send three copies of the pertinent reprint or photocopies

thereof to the IJSEM Editorial Office for confirmation that all of the other requirements for valid publication have been met. It is also a requirement of IJSEM and the ICSP that authors of new species, new subspecies and new combinations provide evidence that types are deposited in two recognized culture collections in two different countries (i.e. documents certifying deposition and availability of type strains). It should be noted that the date of valid publication of these new names and combinations is the date of publication of this list, not the date of the original publication of the names and combinations. The authors of the new names and combinations are as given below, and these authors' names will be included in the author index of the present issue and in the volume author index. Inclusion of a name on these lists validates the publication of the name and thereby makes it available in bacteriological nomenclature. The inclusion of a name on this list is not to be construed as taxonomic acceptance of the taxon to which the name is applied. Indeed, some of these names may, in time, be shown to be synonyms, or the organisms may be transferred to another genus, thus necessitating the creation of a new combination.

\begin{tabular}{|c|c|c|c|c|}
\hline Name/author(s) & Proposed as: & Nomenclatural type ${ }^{\star}$ & Priority $\dagger$ & Reference \\
\hline $\begin{array}{l}\text { Balneimonas flocculans corrig. Takeda et al. } 2004 \ddagger \\
\text { (Balneomonas flocculans }[\text { sic] })\end{array}$ & sp. nov. & $\begin{array}{l}\text { Strain TFB }(=\text { JCM } 11936=\text { KCTC } 12101=\text { IAM } \\
15034=\text { ATCC BAA-817 })\end{array}$ & 3 & 7 \\
\hline Klebsiella variicola Rosenblueth et al. 2004 & sp. nov. & Strain F2R9 $(=$ ATCC BAA-830=DSM 15968)§ & 4 & 6 \\
\hline Lactobacillus spicheri Meroth et al. 2004 & sp. nov. & Strain LTH 5753 (=DSM $15429=$ LMG 21871) & 6 & 5 \\
\hline Micromonospora endolithica Hirsch et al. 2004 & sp. nov. & Strain AA-459 (=DSM $44398=$ NRRL B-24248) & 7 & 4 \\
\hline Treponema azotonutricium Graber et al. 2004 & sp. nov. & Strain ZAS-9 (=DSM $13862=$ ATCC BAA-888) & 5 & 3 \\
\hline Treponema primitia Graber et al. 2004 & sp. nov. & Strain ZAS-2 $(=$ DSM $12427=$ ATCC BAA-887 $)$ & 5 & 3 \\
\hline
\end{tabular}

For references to Validation Lists 1-71, see Int J Syst Bacteriol 49 (1999) 1325. Lists 72-95 were published in Int J Syst Evol Microbiol 50 (2000) 3, 423, 949, 1415, 1699, 1953; and 51 (2001) 1, 263, 793, 1229, 1619, 1945; and 52 (2002) 3, 685, 1075, 1437, 1915; and 53 (2003) 1, 373, 627, 935, 1219, 1701; and 54 (2004) 1, 307.

*Abbreviations: ATCC, American Type Culture Collection, Manassas, VA, USA; CCUG, Culture Collection, University of Göteborg, Göteborg, Sweden; CIP, Collection of the Institute Pasteur, Paris, France; DSM, DSMZ - Deutsche Sammlung von Mikroorganismen und Zellkulturen, Braunschweig, Germany; JCM, Japan Collection of Microorganisms, RIKEN, Saitama, Japan; KCTC, Korean Collection for Type Cultures, Korea Research Institute of Bioscience \& Biotechnology, Yusong, Taejon, Republic of Korea; IAM, Institute of Molecular and Cellular Biosciences, University of Tokyo, Tokyo, Japan; LMG, LMG Culture Collection, Universiteit Gent, Gent, Belgium; NRRL, Agricultural Research Service Culture Collection, National Center for Agricultural Utilization Research, US Department of Agriculture, Peoria, IL, USA.

$\dagger$ Priority number assigned according to the date the documentation and request for validation are received.

$¥$ The genus name has been corrected on validation according to Rule 61 of the Bacteriological Code.

$\S$ The culture collection accession number CFNE 2004 is also cited in the effective publication, but the authors did not provide a certificate of deposit from this collection.

IIDesignated as the type strain and culture collection accession numbers provided on request for validation.

TThe name of the sixth author (R. A. Hutson) is erroneously given as R. A. Hudson in the effective publication. 


\section{References}

1. Collins, M. D., Lundström, T., Welinder-Olsson, C., Hansson, I., Wattle, O., Hudson, R. A. \& Falsen, E. (2004). Streptococcus devriesei sp. nov., from equine teeth. Syst Appl Microbiol 27, 146-150.

2. Fracek, S. P., Jr \& Stolz, J. F. (1985). Spirochaeta bajacaliforniensis sp. n. from a microbial mat community at Laguna Figueroa, Baja California Norte, Mexico. Arch Microbiol 142, 317-325.

3. Graber, J. R., Leadbetter, J. R. \& Breznak, J. A. (2004). Description of Treponema azotonutricium sp. nov. and Treponema primitia sp. nov., the first spirochetes isolated from termite guts. Appl Environ Microbiol 70, 1315-1320.

4. Hirsch, P., Mevs, U., Kroppenstedt, R. M., Schumann, P. \& Stackebrandt, E. (2004). Cryptoendolithic Actinomycetes from
Antarctic sandstone rock samples: Micromonospora endolithica sp. nov. and two isolates related to Micromonospora coerulea Jensen 1932. Syst Appl Microbiol 27, 166-174.

5. Meroth, C. B., Hammes, W. P. \& Hertel, C. (2004). Characterisation of the microbiota of rice sourdoughs and description of Lactobacillus spicheri sp. nov. Syst Appl Microbiol 27, 151-159.

6. Rosenblueth, M., Martínez, L., Silva, J. \& Martínez-Romero, E. (2004). Klebsiella variicola, a novel species with clinical and plantassociated isolates. Syst Appl Microbiol 27, 27-35.

7. Takeda, M., Suzuki, I. \& Koizumi, J. I. (2004). Balneomonas flocculans gen. nov., sp. nov., a new cellulose-producing member of the $\alpha-2$ subclass of Proteobacteria. Syst Appl Microbiol 27, $139-145$. 